\title{
ELECTRONIC QUESTIONNAIRE SYSTEM FOR THE COLLECTION OF RESEARCH DATA WITHIN THE FRAMEWORK OF LMS
}

\section{Milan KLEMENT - Jiří ŠTENCL}

\begin{abstract}
The present essay puts forward a draft of the process for designing and building an electronic questionnaire system usable for collecting research data. These data can then be applied within the framework of statistical processing using computational techniques, such ass multidimensional methods of cluster and factor analysis. The introduced system has been applied in practice in order to collect research data within the project GA ČR No. P407/11/1306 - Evaluation of educational materials for distance learning and e-learning.
\end{abstract}

Key words: e-learning, research surveys, research data, research questionnaire, electronic questionnaire, database.

\section{ELEKTRONICKÝ DOTAZNÍKOVÝ SYSTÉM URČENÝ PRO SBĚR VÝZKUMNÝCH DAT V RÁMCI LMS}

Resumé: Předložená stat' představuje postup návrhu a tvorby elektronického dotazníkového systému využitelného pro sběr výzkumných dat. Tato data mohou sloužit pro potřeby statistického zpracování pomocí výpočetní techniky například při použití multidimensionálních statistických metod shlukové a faktorové analýzy. Představený systém byl $\mathrm{v}$ praxi použit při sběru výzkumných dat $\mathrm{v}$ rámci řešení projektu GA ČR č. P407/11/1306 - Evaluace vzdělávacích materiálů určených pro distanční vzdělávání a e-learning.

Klíčová slova: e-learning, výzkumné šetření, výzkumná data, výzkumný dotazník, elektronický dotazník, databáze.

\section{1 Úvod}

Využití informačních a komunikačních technologií při vzdělávání na všech typech škol se v dnešní době stává samozřjmostí. Informační a komunikační technologie přinášejí velké množství pozitivních efektů, které vhodným způsobem doplňují a podporují vzdělávání. Některé moderní formy studia, $\mathrm{v}$ rámci českých i zahraničních vysokých škol, jsou dokonce na použití informačních a komunikačních technologií postaveny. Jedná se především o distanční vzdělávání realizované formou e-learningu, kdy je celý vzdělávací proces zprostředkováván, ř́zen a vyhodnocován na základě využití výpočetní techniky, specializovaných hypermediálních vzdělávacích materiálů a sofistikovaných softwarových systémů.

Do popředí zájmu pedagogů, domácích i zahraničních, se tedy dostaly otázky, které vymezují nejen obsah elektronických studijních opor, ale také jejich strukturu či použití moderních prvků prezentace učiva, jako jsou multimédia či virtuální realita. Dále se začaly objevovat otázky směřující $\mathrm{k}$ možnostem implementace e-learningu do edukačního procesu firem či školských zařízení. Byla tedy realizována celá řada průzkumů či výzkumů, které měly za cíl explanovat oblast distančních forem vzdělávání, at' již s využitím moderních informačních a komunikačních technologií, či bez jejich využití. Je nutné ale konstatovat, že dříve realizovaná výzkumná šetření většinou nereagovala na soudobé modernizační trendy v oblasti distančního vzdělávání realizovaného formou e-learningu $\mathrm{v}$ podobě, $\mathrm{v}$ jaké byly vymezeny, analyzovány a vyhodnoceny v předcházejících kapitolách této práce.

Autory předloženého článku bylo realizováno dlouhodobé výzkumné šetření v oblasti názorů a postojů studentů na distanční vzdělávání realizované formou e-learningu s využitím sofistikovaných a multimediálně obohacených elektronických studijních opor (1). Obsahovaly a využívaly nástroje pro dosahování kognitivních, afektivních, ale i psychomotorických cílů výuky, v souladu 
$\mathrm{s}$ dř́ve uvedenými modernizačními trendy $\mathrm{v}$ této oblasti.

\section{Důvody vedoucí $k$ tvorbě nástrojů pro plně elektronický sběr dat}

První krok zmíněného realizovaného výzkumného šetření spočíval ve vytvoření podmínek pro jeho realizaci. Nutnou podmínkou bylo zajištění odpovídajícího výzkumného vzorku studentů, kterým by mohl být distribuován výzkumný dotazník. Jelikož bylo důležité, aby se respondenty výzkumného šetření stali především studenti, kteří část studia realizovali distanční formou prostřednictvím LMS systému Unifor, a měli tudíž předchozí či aktuální zkušenost $\mathrm{s}$ touto formou studia, bylo nutné zajistit plně elektronizovaný sběr dat.

Toto bylo zajištěno vytvořením ojedinělého databázového modulu, který byl zakomponován do LMS systému Unifor, ale $\mathrm{z}$ důvodů své modularity je možné jej implementovat nejen do LMS systémů, ale také do systémů studijních agend, a je možné jej tedy využívat nejen pro potřeby prezentovaného výzkumného šetření. Pomocí digitalizovaného dotazníku, který byl navázán na vytvořený databázový systém a LMS Unifor, došlo ke sběru potřebných dat. Tento sběr dat byl zahájen započetím zimního semestru akademického roku 20011/2012 a probíhal do jeho ukončení na následujících vzdělávacích institucích.

- Cyrilometodějská teologická fakulta Univerzity Palackého v Olomouci (CMTF UP).

- Fakulta ekonomická Západočeské Univerzity v Plzni (FE ZČU).

- Fakulta tělesné kultury Univerzity Palackého v Olomouci (FTK UP).

- Filozofická fakulta Univerzity Palackého v Olomouci (FF UP).

- Justiční Akademie v Kroměříži (JA Kroměříž).

- Pedagogická fakulta Univerzity Palackého v Olomouci (PdF UP).
- Pedagogická fakulta Univerzita Hradec Králové (PdF UHK).

- Právnická fakulta Univerzity Palackého v Olomouci (PF UP).

\section{Popis struktury vytvořeného nástroje}

Tento nástroj byl navržen a naprogramován pomocí programovacích jazyků JAVA (2) a PHP (3), které jsou vhodné pro tvorbu webových aplikací, nebot' LMS systém využívá webového rozhraní pro prístup ke svému obsahu. Jelikož LMS systém Unifor všechny části svého obsahu uchovává $\mathrm{v}$ interní databázi postavené na technologii Microsoft SQL(4), bylo nutné i náš databázový systém vybudovat na vhodné databázové struktuře, která by jednak zajištovala kompatibilitu s databázovým systémem od firmy Microsoft, a to $\mathrm{z}$ důvodu jeho velké rozšířenosti, ale umožnila i napojení na Open source (5), databázové systémy, které jsou využívány u některých nekomerčních LMS systémů. Byl vybrán databázový systém MySQL (6), který je šířen a používán pod licencí GNU GPL (česky „Všeobecná veřejná licence GNU“). Propojení jednotlivých databází bylo provedeno pomocí technologie AJAX (6). Pomocí této technologie (Asynchronous JavaScript And XML) byl vytvořen řídící modul (7), který zajišt'oval ověrování a přenos dat mezi databázemi MSSQL a MySQL, a dále pak mezi webovým rozhraním LMS systému Unifor (PHP část kódu) a webovým rozhraním elektronického dotazníku (JavaScript část kódu).

Strukturu databázového dotazníkového systému, včetně vazeb na jednotlivé související technologie a složky LMS systému, pro zjednodušení uvádíme pouze na obrázku, nebot' detailnější popis jednotlivých částí kódů a programovacích struktur by značně přesáhl rozsah předloženého článku a nebylo by ani účelné tímto čtenáře zatěžovat. 


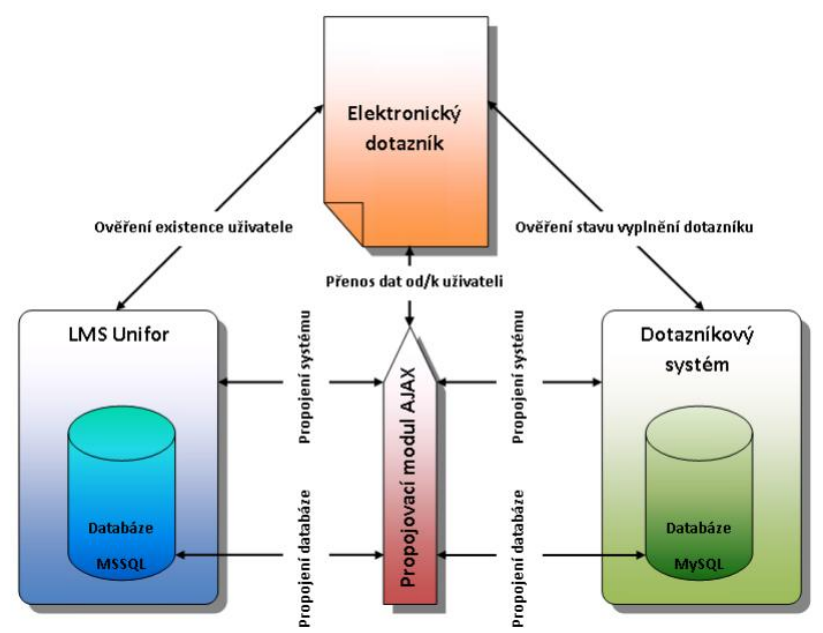

Obrázek 1 - Struktura a vazby databázového dotazníkového systému

Z důvodu realizace výzkumného šetření na více školách bylo nutné databázový dotazníkový systém rozšírit a přizpůsobit jej těmto podmínkám. Původní návrh počítal s tím, že bude nutné využít a propojit pouze dvě fyzické databáze, databázi LMS Unifor pro ověření existence uživatele a databázi dotazníkového systému pro ověrení stavu vyplnění elektronického dotazníku uživatelem (8). V nových podmínkách bylo nutné zajistit propojení celkem devíti fyzických databází, osmi fyzických databází LMS Unifor dislokovaných na jednotlivých školách zapojených do výzkumného šetření s devátou fyzickou databází dislokovanou na serveru PdF UP v Olomouci. Z tohoto důvodu byl původní koncept přepracován a jeho vizualizaci představuje obrázek číslo 2 .

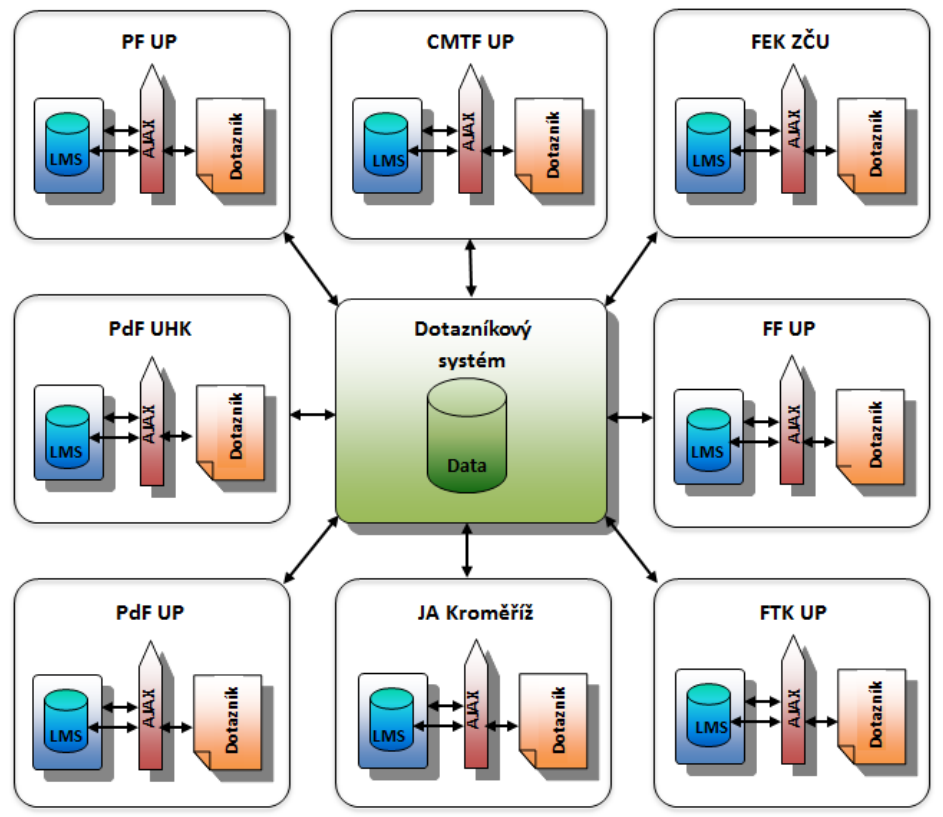

Obrázek 2 - Vazby upraveného databázového dotaznikového systému s LMS škol

Takto rozsáhlý celek by bylo nesnadné ř́idit bez existence centrální konzoly pro správu. Bylo tedy přistoupeno $\mathrm{k}$ vytvoření řídícího modulu, který byl schopen centrálně ovládat jednotlivé propojovací moduly fyzických databází LMS Unifor dislokovaných na jednotlivých školách $\mathrm{s}$ centrální databází dotazníkového systému. Tento modul sloužil také k průběžnému zobrazování dosavadního postupu 
sběru dat na jednotlivých školách. Zobrazení řídícího modulu je uvedeno na obrázku 3.

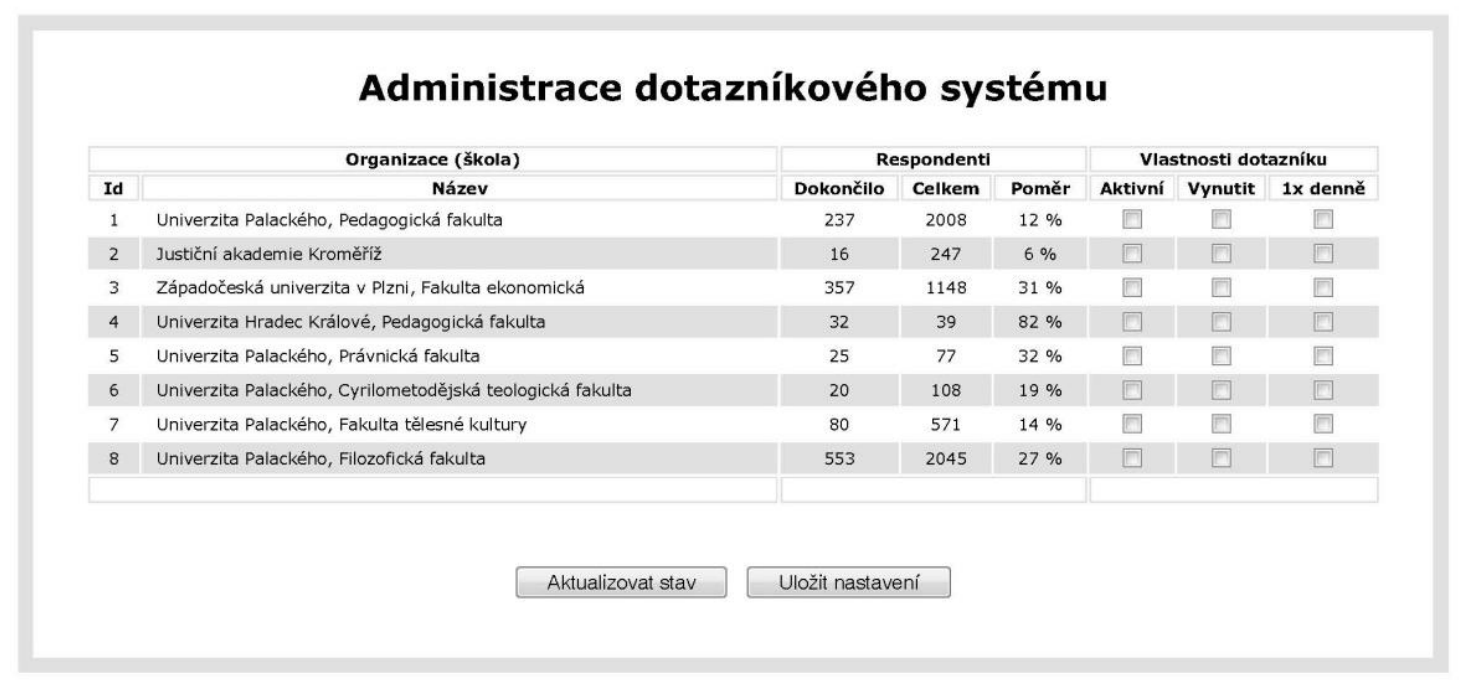

Obrázek 3 - Řídici modul databázového dotazníkového systému

4 Funkce pro zajištění informovanosti respondentů $v$ rámci vytvořeného nástroje

Dalším, $\mathrm{v}$ pořadí třetím úkolem, $\mathrm{v}$ této části prrípravy podmínek realizace výzkumného šetření v podmínkách osmi vysokoškolských institucí, bylo zajištění anonymizace respondentů, jejich dostatečné informovanosti o základních vlastnostech a důvodech sběru dat pomocí elektronického dotazníku. Zde bylo využito zkušeností a vyvinutých postupů $\mathrm{z}$ realizace předchozího výzkumného šetření na půdě $\mathrm{PdF}$ UP v Olomouci a byly tedy použity stejné techniky pro anonymizaci respondentů (8). Výhodou byl také fakt, že skupina respondentů byla rozdělena do osmi podmnožin, dle př́íslušnosti $\mathrm{k}$ dané škole, takže bylo možné doplnit označení jednotlivých respondentů o tento údaj.

Poslední částí prípravy podmínek pro realizaci výzkumného šetření bylo vytvoření uživatelského rozhraní elektronického dotazníku, které by opět obsahovalo nejen vlastní dotazníkové otázky, ale také informaci o způsobu jeho vyplnění, vysvětlení důvodu sběru dat a také pokyny $\mathrm{k}$ vyplnění celého dotazníku. Celé uživatelské rozhraní elektronického dotazníku bylo koncipováno tak, aby práce $\mathrm{s}$ ním byla uživatelsky př́ijemná a použité ovládací prvky byly uživateli důvěrně známé a také.

Takto koncipovaný elektronický dotazník, uvedený podpornými pokyny k vyplnění, byl ve všech LMS systémech škol zapojených ve výzkumném šetření uveden vysvětlujícím textem, jenž se ve formě samostatného okna zobrazoval všem uživatelům, kteří nedokončili vyplnění dotazníku. Uživatel měl samozřejmě opět v jakékoliv fázi vyplnění dotazníku odmítnout či přerušit. Na obrázku 4 je zobrazeno úvodní informační okno elektronického dotazníku, který byl distribuován v rámci osmi vysokoškolských institucí. 


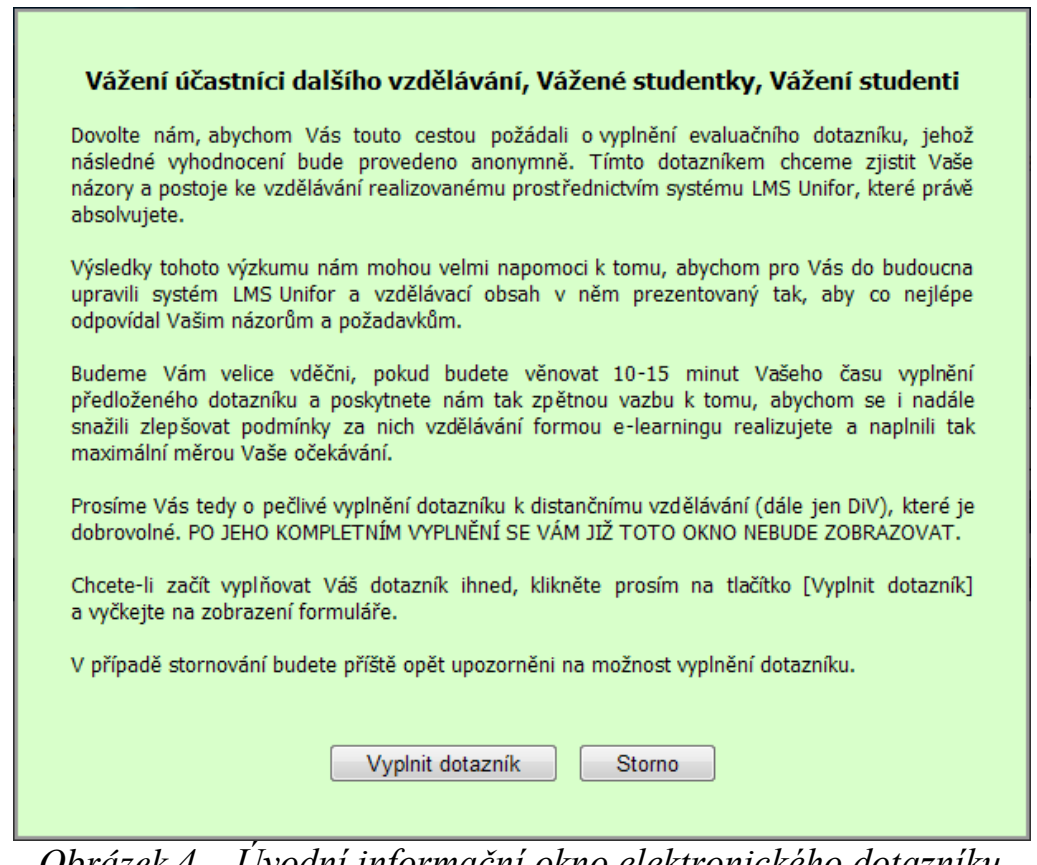

Po dokončení výše uvedených příprav bylo možné zahájit sběr a vyhodnocení dat, nutných pro ověření uvedeného výzkumného předpokladu a hypotéz na základě použití vícerozměrných statistických metod. Sběr potřebných dat probíhal od 1. 10. 2011 do 3. 2. 2012, to znamená po dobu jednoho semestru. Pomocí popsaného databázového dotazníkového systému se podařilo oslovit celkem 6243 studentů osmi vysokoškolských institucí, kteří kompletně vyplnili 1625 dotazníků, jež bylo možné použít pro statistické zpracování. Návratnost dotazníků tedy dosáhla, prri tomto způsobu sběru dat celkem obvyklé hodnoty $26 \%$.

\section{Závěr}

Prezentovaný nástroj určený pro sběr výzkumných dat, postavený na platformě AJAX a MySQL se v praxi plně osvědčil a umožnil získat celou řadu výzkumných dat, které by se při klasickém sběru dat pomocí „papírových“ dotazníků nepodařilo získat.

Mezi hlavní výhody sběru výzkumných dat touto formou patří především tyto:

- Vysoká míra návratnosti dotazníků. Tuto skutečnost můžeme doložit tím, že $\mathrm{v}$ rámci použití tohoto nástroje dosahovala návratnost plně vyplněných dotazníků výše $26 \%$.

- Uživatelský komfort pro respondenty výzkumu. Respondenti výzkumu velmi snadno manipulují s dotazníkem a nejsou zatěžováni složitou manipulací s papírovým dotazníkem.
- Jednoznačné zacílení na relevantní výzkumný vzorek. Tímto způsobem sběru dat bylo zajištěno, že se výzkumný dotazník dostane skutečně pouze $\mathrm{k}$ těm respondentům, kteří byli cílovou skupinou výzkumu.

- Rychlé a snadné použití získaných dat pro zpracování $\mathrm{s}$ využití statistického software. Při použití „papírového“ dotazníku je velmi namáhavé a zdlouhavé přenesení získaných údajů do elektronické podoby vhodné pro počítačové zpracování dat.

- Omezení chybovosti dat v dotazníku. Každý respondent výzkumu může velmi snadno a rychle opravit př́padný omyl a je také eliminována chybovost při přenášení dat $\mathrm{z}$ „papírového“ dotazníku do použitelné elektronické podoby.

\section{Literatura}

[1] KLEMENT, M., CHRÁSKA, M. Vymezení kritérií evaluace elektronických distančních opor. In: Media4u Magazine. 2011. Praha - EU: Sv. 1, č. 2, s. 69-72. ISSN 1214-0554.

[2] VIRIUS, M. Programování v Javě. 1. vyd., Praha: České vysoké učení technické, 2010. 304 s. ISBN 978-80-01-04518-3.

[3] THOMPSON, E., NOWICKI, S. PHP 6 programujeme profesionálně. 1. vyd., Brno: Computer Press, 2010. 718 s. ISBN 978-80-2513127-5. (překlad O. Gibl). 
[4] LACKO, L. Jak vyzrát na Microsoft SQL Server 2008 - správa, konfigurace, programování. 1. vyd., Brno: Computer Press, 2009. 469 s. ISBN 978-80-251-2101-6. (překlad R. Okáč).

[5] ŠTĚDROŇ, B. Open Source software ve veřejné správě a soukromém sektoru. 1. vyd., Praha: Grada, 2009. 124 s. ISBN 978-80-2473047-9.

[6] KOFLER, M. Mistrovství v MySQL 5 kompletni prưvodce webového vývojář́e. 1. vyd., Brno: Computer Press, 2007. 805 s. ISBN 97880-251-1502-2. (překlad J. Svoboda, O. Baše, J. Černý).

[7] OLEHLA, M. Počitače a programováni studijni podklady pro 1. ročník SF. 1. vyd., Liberec: Technická univerzita, 1997. 156 s. ISBN 80-7083-231-2.

[8] KLEMENT, M., CHRÁSKA, ŠTENCL, J. M. Tvorba nástroje pro sběr výzkumných dat v prostředí LMS Unifor postaveného na platformě AJAX a MySQL. In: Sborník z mezinárodni védecké konference Technológie vzdelávania $v$ príprave ucitelov prírodovedných a technických predmetov. 1. vyd., Prešov: FHPV
PU v Prešove, 2011. s. 166 - 170. ISBN 978-80555-0438-4.

Př́spěvek vznikl za podpory GAČR v rámci řešení projektu č. P407/11/1306

„Evaluace vzdělávacích materiálů určených pro distanční vzdělávání a elearning ${ }^{66}$

Lektoroval: Doc. PhDr. Miroslav Chráska, Ph.D.

Milan Klement, PhDr. Ph.D.,

Katedra technické a informační výchovy, Pedagogická fakulta UP, Žižkovo nám. 5, 77140 Olomouc, $\check{C} R$, tel. 00420585635811 , e-mail: milan.klement@upol.cz Jiř̌́ Štencl, Ing.

Odbor proděkana pro informační a vzdělávací technologie,

Pedagogická fakulta UP, Žižkovo nám. 5, 77140 Olomouc, $\check{C} R$, tel. 00420585635040 , e-mail: jiri.stencl@upol.cz 